\title{
Cytotoxic Effects Of N-(4-Chlorophenyl)-1H-Indole-2-Carboxamide On Bone Cancer Cells
}

\section{N- (4-Klorofenil) -1h-İndol-2-Karboksamidin Kemik Kanseri Hücreleri Üzerine Sitotoksik Etkisi}

\author{
Medine Taşdemir ${ }^{1}$, Mete Emir Özgürses ${ }^{1}$, Hakan Darıcı ${ }^{2}$, Nazli Ece ORDUERI ${ }^{3}$ \\ ${ }^{1}$ Biruni Üniversitesi Mühendislik ve Doğa Bilimleri Fakültesi, Moleküler Biyoloji ve Genetik Anabilim Dalı \\ ${ }^{2}$ İstinye Üniversitesi, Tıp Fakültesi, Histoloji ve Embriyoloji Anabilim Dalı \\ ${ }^{3}$ Biruni Üniversitesi, Tıp Fakültesi, Histoloji ve Embriyoloji Anabilim Dalı
}

\section{ÖZET}

GÍRIŞ̧ ve AMAÇ: Osteosarkom, mezenkimal dokulardan türetilmiş, yüksek maligniteli yaygın bir tümördür. Osteosarkom genellikle ergenlerde görülür ve büyüme hızlıdır, metastaz ve mortalite oranları yüksektir ve prognozu zayıftır. Kemoterapötik tedavilere cevap verilmemesi, yeni terapötik yöntemlerin araştırılmasının önemini gösterir. N-(4-klorofenil)-1H-indol-2-karboksamid, etkili antioksidan özellikler gösteren, aynı zamanda tirozin kinaz hedefleri üzerinde etkisi olan ümit verici bir terapötik ajandir. Bu bağlamda çalışmamızda, N- (4Klorofenil) -1 H-İndol-2-Karboksamid'in Saos-2 osteosarkom hücre hattının proliferasyon, apoptoz ve hücre iskeleti üzerindeki etkilerini araştırdık. N- (4-klorofenil) -1 H-indol-2-karboksamidin sitotoksik etkilerini, osteosarkom hücrelerine dayanarak zamana bağlı olarak imatinib mesilatın farmakolojik dozlarını doğrulayarak değerlendirdik.

YÖNTEM ve GEREÇLER: Bu çalışmada, N- (4-klorofenil) -1 H-indol-2-karboksamid ve Imatinib mesilat dozlarının osteosarkom Saos-2 hücrelerinin hücre canlılığı üzerindeki etkileri MTT tahlili kullanılarak gerçekleştirildi. Ezrin ekspresyon seviyeleri immünofloresan boyama ile incelendi.

BULGULAR: Antiproliferatif aktivitenin sonuçları, N- (4-klorofenil) -1 H-indol-2-karboksamidin, Saos-2 hücrelerinin hücre proliferasyonunu doza ve zamana bağlı bir şekilde inhibe ettiğini gösterdi. Daha düşük dozlarda N-(4-klorofenil)-1H-indol-2-karboksamidin bile, imatinib mesilat farmakolojik dozlariyla karşılaştırıldığında osteosarkom hücre dizileri üzerinde etkili olduğunu bulduk.

TARTIŞMA ve SONUÇ: Bu çalışmada ilk kez yeni sentezlenen indol türevi molekülü N-(4-klorofenil)-1Hindol-2-karboksamidin in vitro osteosarkom hücre hattında direnç açısından değerlendirildi. Tüm bu sonuçlar, N(4-Klorofenil)-1H-İndol-2-Karboksamidin osteosarkom büyümesini ve metastazı inhibe etmek için potansiyel bir terapötik ajan olarak geliştirilebileceğini gösterdi.

Anahtar Kelimeler: Osteosarkom, N-(4-Klorofenil)-1H-İndol-2-Karboksamid, hücre proliferasyonu, reaktif oksijen türleri,tirozin kinazlar

\section{ABSTRACT}

INTRODUCTION: Osteosarcoma is a common tumor of high malignancy, usually derived from mesenchymal tissues. The lack of response to chemotherapeutic treatments indicates the importance of investigating new therapeutic methods. Indole, which is known to inhibit proliferation on cancer cells, is new synthesized as a derivative of this molecule of $\mathrm{N}$ - (4-chlorophenyl) - $1 \mathrm{H}$-indole-2-carboxamide, has an effect on osteosarcoma cell line. We evaluated the cytotoxic effects of $\mathrm{N}$ - (4-chlorophenyl) -1H-indole-2-carboxamide by verification of pharmacological doses of imatinib mesylate based on time on osteosarcoma cells.

METHODS: In the present study, the effects of $\mathrm{N}$-(4-chlorophenyl)-1H-indole-2-carboxamide and Imatinib mesylate doses on cell viability of osteosarcoma Saos-2 cells were conducted using MTT assay. Ezrin expression levels was examined by immunofluorescence staining.

RESULTS: The results of the antiproliferative activity showed that $\mathrm{N}$ - (4-chlorophenyl) -1 H-indole-2carboxamide inhibited cell proliferation of Saos-2 cells in a dose- and time-dependent manner. We found that even lower doses of $\mathrm{N}$ - (4-chlorophenyl) -1H-indole-2-carboxamide was effective on osteosarcoma cell lines when we compared with imatinib mesylate pharmacological doses.

DISCUSSION AND CONCLUSION: In this study, for the first time the newly synthesized indole derivative molecule, N- (4-chlorophenyl) -1 H-indole-2-carboxamide was evaluated for resistance in vitro Saos-2 cell line. 
All these results showed that N- (4-Chlorophenyl) -1 H-Indole-2-Carboxamide can be developed as a potential therapeutic agent for inhibiting osteosarcoma growth and metastasis.

Keywords: Osteosarcoma, N-(4-Chlorophenyl)-1H-Indole-2-Carboxamide, cell proliferation, reactive oxygen species, thyrosine kinases.

\section{INTRODUCTION}

Bone performs important functions in the body, such as movement, support and protection of soft tissues, storage of calcium and phosphate, and housing of bone marrow. Bone has the power to regenerate and repair constantly throughout the entire life (1). This process, called bone modification, involves different cell types and can be initiated in response to changes in biomechanical loading or to replace the old, microvessed bone with new, mechanically stronger bone (2).

The bone is a common site for metastasis. When cancer cells in the primary tumor are transported to the bone, bone metastasis occurs (3). Prostate, breast and lung cancers spread in the bone and produce metastatic lesions. Bone metastasis does not begin from the bones, but is transported from the primary tumor site. On the other hand, primary bone cancers are rare cancers where the primary tumor actually begins to bone. Primary types of bone cancer are: osteosarcoma, chondrosarcoma, Ewing's sarcoma, and chordoma (4).

Osteosarcoma is the most common type of primary bone malignancy, a nonhemopoietic malignant tumor of the skeletal system derived from primitive mesenchymal cells (5). While its occurrence is low, osteosarcoma predominantly affects adolescents and young adults and is fatal if left untreated. Despite modern treatment protocols that combine chemotherapy, surgery and sometimes radiotherapy, the 5-year survival rate for patients diagnosed with osteosarcoma remains between $60-70 \%(5,6)$. There is therefore a need for novel molecular targeted therapies that are more effective and have less toxicity.

Inhibitors of receptor tyrosine kinases (RTKs) repres. ent a promising new class of targeted anticancer therapy. Protein tyrosine kinases are important signaling molecules with highly regulated activity (7). Their main function is to catalyze the transfer of phosphate of ATP to tyrosine residues on protein substrates. This produces binding sites for adapter proteins and downstream signaling molecules that lead to changes in cell proliferation, differentiation, migration, survival or other metabolic activities. One promising approach is the detailed targeting of transmembrane RTKs incorporated into such types of bone cancer $(8,9)$. Another important target in anticancer treatment is reactive oxygen species (ROS). Reactive oxygen species are highly reactive molecules of various chemical species, including radical and non-radical oxygen species. (10). Oxidative stress occurs as a result of an overproduction of ROS that is not balanced with sufficient antioxidants. Changes in ROS and antioxidant systems appear to play a role in the pathogenesis of bone loss (11).

There is an urgent need to develop a new and effective drug that not only kills the primary tumor but also suppresses metastasis. However, in the last 10 years, better knowledge of oncogenic processes in osteosarcoma has led to the development of new therapeutic approaches based on new drugs or in combination with conventional chemotherapy (12).

Imatinib mesylate (Gleevec, Novartis Pharma), used in the treatment of cancer, is a selective active tyrosine kinase inhibitor having activity against a large tyrosine kinase 
protein panel comprising the $\mathrm{Bcr} / \mathrm{Abl}$, c-kit, MCSF receptor and PDFG receptor. (13). Many studies have shown that imatinib mesylate inhibits osteoclast differentiation along the M-CSFR pathway and activates osteoblast differentiation along the PDGFR pathway, two key cells that control tumor growth in the vicious circle. Osteoblasts and their precursors are the cellular targets of imatinib mesylate (14).

Over the years, better knowledge of oncogenic processes in osteosarcoma has led to the development of new therapeutic approaches based on new single drugs or in combination with conventional chemotherapy.

Diets rich in vegetables are known to be useful in the prevention of cancer. The vegetables of the Brassica genus (cabbage, broccoli, cauliflower and Brussels sprouts) have shown that they prevent cancer due to glycosinolates found in Brassica (15). These vegetables make the most contribution to glucosinolate intake. Glucosinolates with an indole side chain form indole. Indole derivatives form an important class of therapeutic agents in medical chemistry, including anticancers and antioxidants (16). In previous studies, they described novel $\mathrm{N}$ substituted indole- 2 carboxamide and indole-3acetamide derivatives with highly effective antioxidant properties (17). In the last study, the same group (18) described the new N- (4chlorophenyl) -1 H-indole-2-carboxamide derivative having highly effective antioxidant properties.

In this study, we intended to evaluate the cytotoxic effect of newly synthesized $\mathrm{N}$ (4-chlorophenyl) -a 1H-indole-2-carboxamide molecule on osteosarcoma cell line and comparison of the dose with N- (4chlorophenyl) -1H-indole-2-carboxamide with reference to pharmacologically used imatinib mesylate and trying to provide experimental evidence and facilitate the discovery of new approaches for the prevention and treatment of human osteosarcoma.

\section{MATERIAL METHOD}

\section{Cells and Culture Conditions}

The human osteosarcoma cell line Saos-2 was obtained from ATTC (Manassas, VA, USA). Saos2 cells were cultured in Dulbecco's Modified Eagle's Medium (DMEM; Thermo Fisher Waltham, USA) supplemented with $10 \%$ fetal bovine serum (FBS; Gibco, Gaithersburg, USA) and $1 \%$ penicillin and streptomycin. The Saos- 2 cells were cultured in an incubator with $5 \% \mathrm{CO} 2$ at $37^{\circ} \mathrm{C}$, and the medium was changed once every 3 days, followed by passage when $80 \%$ of them were fused. When $80 \%$ of the cultured cells were fused, the cell culture medium was removed, rinsed with PBS, followed by digestion with $\% 0,125$ Trypsin for $3 \mathrm{~min}$ and then gentle pipetting to digest the adherent cells. DMEM medium containing 10\% FBS was added to stop digestion, followed by centrifugation at $10,000 \times \mathrm{rpm}$ for $5 \mathrm{~min}$. Then, the supernatant was removed, the medium was added for resuspension, and the cells continued to be cultured. Finally, the cells were collected for experiments.

\section{Drug Dose Preparation}


Table 1: Suitable dosages for $\mathrm{N}$-(4-chlorophenyl)-1H-indole-2-carboxamide and time-dependent cell culture for MTT analysis

\begin{tabular}{|c|c|c|c|c|c|}
\hline $\begin{array}{l}\text { Doses of N-(4- } \\
\text { chlorophenyl)- } \\
1 \mathrm{H} \text {-indole-2- } \\
\text { carboxamide }\end{array}$ & $\begin{array}{l}\text { Amount of drug } \\
\text { added to each } \\
\text { well/stock } \\
\text { solution }\end{array}$ & $\begin{array}{l}\text { Amount } \\
\text { of } \\
\text { DMEM } \\
\text { added to } \\
\text { each well }\end{array}$ & Cell number & $\begin{array}{l}\text { Used cell } \\
\text { culture dish } \\
(\text { well surface } \\
\left.\text { area: } \mathrm{mm}^{3}\right)\end{array}$ & $\begin{array}{l}\text { Drug } \\
\text { exposure } \\
\text { time(hour) }\end{array}$ \\
\hline $1 \mu \mathrm{M}$ & $0,4 \mu \mathrm{l} / 250 \mu \mathrm{M}$ & $99.6 \mu \mathrm{l}$ & $100 \mu \mathrm{l} / 20.000$ cell & 96 well $/ 4 \mathrm{~mm}^{3}$ & $24 \mathrm{~h}$ \\
\hline $2.5 \mu \mathrm{M}$ & $1 \mu \mathrm{l} / 250 \mu \mathrm{M}$ & $99 \mu \mathrm{l}$ & $100 \mu \mathrm{l} / 20.000$ cell & 96 well $/ 4 \mathrm{~mm}^{3}$ & $24 \mathrm{~h}$ \\
\hline $5 \mu \mathrm{M}$ & $2 \mu \mathrm{l} / 250 \mu \mathrm{M}$ & $98 \mu \mathrm{l}$ & $100 \mu \mathrm{l} / 20.000$ cell & $96 \mathrm{well} / 4 \mathrm{~mm}^{3}$ & $24 \mathrm{~h}$ \\
\hline $10 \mu \mathrm{M}$ & $0.25 \mu \mathrm{l} / 4 \mathrm{mM}$ & $99.75 \mu \mathrm{l}$ & $100 \mu \mathrm{l} / 20.000$ cell & $96 \mathrm{well} / 4 \mathrm{~mm}^{3}$ & $24 \mathrm{~h}$ \\
\hline $20 \mu \mathrm{M}$ & $0.50 \mu \mathrm{l} / 4 \mathrm{mM}$ & $99.5 \mu \mathrm{l}$ & $100 \mu \mathrm{l} / 20.000$ cell & 96 well/ $4 \mathrm{~mm}^{3}$ & $24 \mathrm{~h}$ \\
\hline $30 \mu \mathrm{M}$ & $0.75 \mu \mathrm{l} / 4 \mathrm{mM}$ & $99.25 \mu \mathrm{l}$ & $100 \mu \mathrm{l} / 20.000$ cell & 96 well $/ 4 \mathrm{~mm}^{3}$ & $24 \mathrm{~h}$ \\
\hline $40 \mu \mathrm{M}$ & $1 \mu \mathrm{l} / 4 \mathrm{mM}$ & $99 \mu \mathrm{l}$ & $100 \mu \mathrm{l} / 20.000$ cell & 96 well $/ 4 \mathrm{~mm}^{3}$ & $24 \mathrm{~h}$ \\
\hline
\end{tabular}

$\mathrm{N}$-(4-chlorophenyl)-1H-indole-2-carboxamide was dissolved in DMSO to a stock concentration of $4 \mathrm{mM}$ and stored at $+4{ }^{\circ} \mathrm{C}$. The final concentration of DMSO was no greater than $0.1 \%$. This concentration of solvent had no effect on cell viability (measured by MTT assay). Imatinib Mesylate was dissolved in distilled water absolute to $42.3 \mathrm{mM}$ stock concentration and then diluted to the required concentrations, with complete cell culture medium. Dose-response studies were carried out in order to determine the suitable doses for further experiments.Drug treatment was performed treating cells with different concentrations (shown in Table 1 and 2) of of $\mathrm{N}$-(4-chlorophenyl)-1H-indole-2carboxamide and Imatinib mesylate.

\section{Detection of cell proliferation by MTT Assay}

The cell viability was evaluated by MTT assay. Saos-2 cells were seeded in 96-well plates at a density of $2 \times 104$ cells/well. Unused wells in each plate were used as blanks or medium controls. Then, the cells were exposed in the above-mentioned different concentrations of imatinib and $\mathrm{N}$-(4-chlorophenyl)-1H-indole-2carboxamide. The cells were cultured in an incubator with $5 \% \mathrm{CO} 2$ at $37^{\circ} \mathrm{C}$ for $24 \mathrm{~h}$. After $24 \mathrm{~h}, 10 \mu \mathrm{L}$ of MTT solution was added to each well and incubated for $4 \mathrm{~h}$ at $37^{\circ} \mathrm{C}$. Then, the medium was replaced with $100 \mu \mathrm{L}$ of the Solubilization solution (SDS) into each well to dissolve the precipitated formazan and incubate for another $24 \mathrm{~h}$. SPECTROstar nano absorbance plate reader measured spectrophotometric absorbance taken with a reference wavelength of $>650 \mathrm{~nm}$. Finally, the optical density (proportional to the number of live cells) was assessed at $570 \mathrm{~nm}$ with a Microplate Reader Bio-Rad 550. The readings from blank-medium wells were subtracted from all of the other values, and the percentage of growth for treated cells, compared with untreated cells, was calculated. All the results were performed in triplicate, and all data were expressed as the mean $\pm \mathrm{SD}$.

\section{Immunofluorescence Analysis}


Table 2: Suitable dosages for imatinib mesylate and time-dependent cell culture for MTT analysis

\begin{tabular}{|c|c|c|c|c|c|}
\hline $\begin{array}{l}\text { Doses of N-(4- } \\
\text { chlorophenyl)- } \\
1 \mathrm{H} \text {-indole-2- } \\
\text { carboxamide }\end{array}$ & $\begin{array}{l}\text { Amount of drug } \\
\text { added to each } \\
\text { well/stock } \\
\text { solution }\end{array}$ & $\begin{array}{l}\text { Amount of } \\
\text { DMEM } \\
\text { added to each } \\
\text { well }\end{array}$ & $\begin{array}{l}\text { Cell number } \\
(\mu \backslash \backslash \text { cell) }\end{array}$ & $\begin{array}{l}\text { Used } \\
\text { culture dish } \\
(\text { well surface } \\
\left.\text { area: } \mathrm{mm}^{3}\right)\end{array}$ & $\begin{array}{l}\text { Drug } \\
\text { exposure } \\
\text { time(hour) }\end{array}$ \\
\hline $10 \mu \mathrm{M}$ & $0.125 \mu \mathrm{I} / 8 \mathrm{mM}$ & $99,875 \mu \mathrm{l}$ & $100 \mu \mathrm{J} \backslash 20.000$ cell & 96 well $\backslash 4 \mathrm{~mm}^{3}$ & $24 \mathrm{~h}$ \\
\hline $20 \mu \mathrm{M}$ & $0.25 \mu \sqcap \wedge \mathrm{mM}$ & $99,75 \mu \mathrm{l}$ & $100 \mu \mathrm{l} \backslash 20.000$ cell & 96 well $\backslash 4 \mathrm{~mm}^{3}$ & $24 \mathrm{~h}$ \\
\hline $30 \mu \mathrm{M}$ & $0.375 \mu \mathrm{l} / 8 \mathrm{mM}$ & $99,625 \mu \mathrm{l}$ & $100 \mu \mathrm{I} \backslash 20.000$ cell & 96 well $\backslash 4 \mathrm{~mm}^{3}$ & $24 \mathrm{~h}$ \\
\hline $40 \mu \mathrm{M}$ & $0.5 \mu \mathrm{l} / 8 \mathrm{mM}$ & $99,5 \mu \mathrm{l}$ & $100 \mu \mathrm{J} \backslash 20.000$ cell & 96 well $\backslash 4 \mathrm{~mm}^{3}$ & $24 \mathrm{~h}$ \\
\hline
\end{tabular}

The cell lines used in this study were a osteosarcoma cell line Saos-2. Cells were grown in $37^{\circ} \mathrm{C}$ in a $5 \% \mathrm{CO} 2$ environment in culture media recommended by the provider with the addition of $10 \%$ FBS. For immunofluorescent experiments, 12-well glass bottom plates were used and 100,000 cells were seeded per well. The cells were treated for 15 min with freshly prepared ice-cold $4 \%$ paraformaldehyde (PFA). Fixed cells were permeabilised with $0.1 \%$ Triton-X100 in PBS for $10 \mathrm{~min}$. PBS was added three times for 5 min per round. The cells were then stained with and incubated over night in $4^{\circ} \mathrm{C}$. After washing, 4,6-diamidino-2-phenylindole (DAPI) staining and stored at $4^{\circ} \mathrm{C}$ in the dark. Micrographs were obtained on a Zeiss equipped with an Axiocam color chargecoupled device camera. Images were recorded and treated on computer through the Axiovisiontm software. Adobe Photoshop (Adobe Systems) was used for processing of images.

\section{Statistical Analysis}

Measurements in each experiment was repeated independently three times in triplicate. For quantitative data, results are reported as the mean \pm S.D. To determine the differences between groups, one-way analysis of variance (ANOVA) was carried out using
GrapPad software (version 17.0). A P value of less than 0.05 was considered statistically significant. $* \mathrm{P}<0.05, * * \mathrm{P}<0.005$.

\section{RESULTS}

\section{Cell Morphology of Saos-2 cell line}

Saos-2 cells sown in a $25 \mathrm{~cm} 2$ flask were optimized with total medium in cell culture. The cells were observed 3 days after the initiation of the cell culture. We observed cell agglutination like mimicking bone cell morphology in vitro. We confirmed the day of proliferation for the following drug administration steps.

Anti-proliferative Effects of $\mathrm{N}$ - (4chlorophenyl) -lH-indole-2-carboxamide on Saos-2 Cell Line

The anticancer activities of N-(4Chlorophenyl)-1H-İndole-2-Carboxamide were evaluated in Saos-2 cells. Saos-2 osteosarcoma cells were treated with gradient concentrations of $\mathrm{N}$-(4-Chlorophenyl)-1HIndole-2-Carboxamide from 1 to $40 \mu \mathrm{M}$ for 24 h. As displayed in Figure 1, different doses of $\mathrm{N}$-(4-chlorophenyl)-1H-Indole-2-Carboxamide showed dose-dependent cytotoxicity on Saos-2 cells. To further evaluate whether N-(4chlorophenyl)-1H-indole-2-carboxamide could inhibit the proliferation of osteosarcoma cells, 
optimized with $2.5 \mu \mathrm{M}$ and $20 \mu \mathrm{M}$ doses and immunoflurosecence staining was conducted after $\quad \mathrm{N}$-(4-chlorophenyl)-1H-indole-2carboxamide treatment.

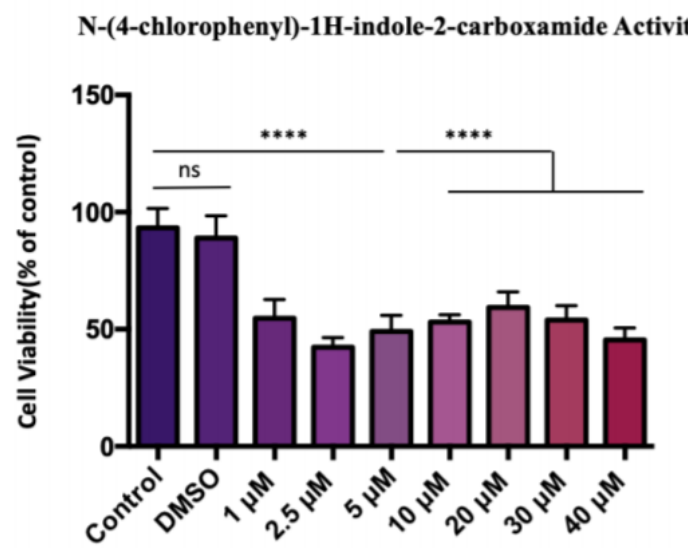

Figure 1. N-(4-chlorophenyl)-1H-indole-2carboxamide inhibits in a dose dependent manner the osteosarcoma cells proliferation. The effects of different doses of $\mathrm{N}$ - (4chlorophenyl) -1 H-indole-2-carboxamide on the proliferation of Saos-2 cells. Data are expressed as means \pm SD from three independent experiments $(* \mathrm{P}<0.001)$

\section{Antiproliferative Effects of Imatinib Mesylate on Saos-2 Cell Line}

The anticancer activities of Imatinib Mesylate at concentrations of 10 to $40 \mu \mathrm{M}$ were evaluated on Saos-2 osteosarcoma cells. Belong to our time-dependent data, as shown in Figure 2, the $40 \mu \mathrm{M}$ dose was more effective than the $10 \mu \mathrm{M}, 20 \mu \mathrm{M}$ and $30 \mu \mathrm{M}$ doses in Saos-2 cells at 24 hours. We found that the correlation between doses and time of administration was important for cell viability of Saos-2 osteosarcoma cells.

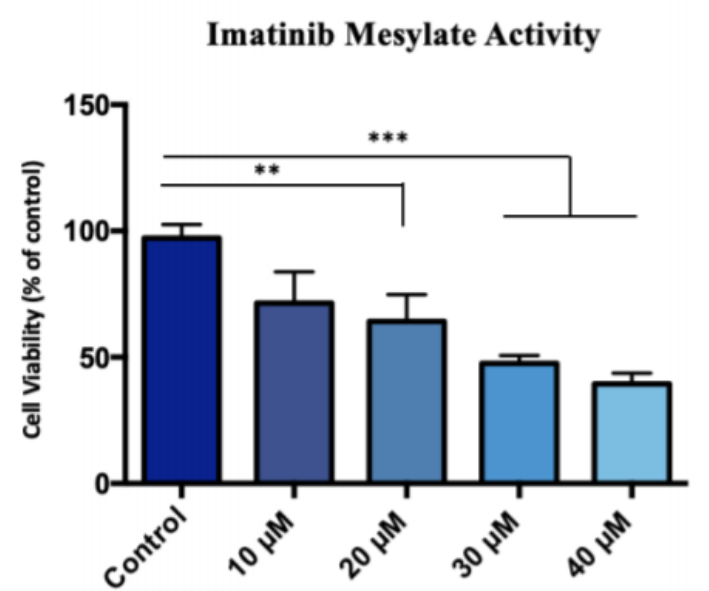

Figure 2. Imatinib mesylate inhibits in a dose dependent manner the osteosarcoma cells proliferation. The effects of different doses of imatinib mesylate on the proliferation of Saos2 cells. Data are expressed as means $\pm \mathrm{SD}$ from three independent experiments $(* \mathrm{P}<$ $0.001)$

Effects of $\mathrm{N}$-(4-chlorophenyl)-1H-indole-2carboxamide on ezrin expression in SaOS2 cells

We evaluated ezrin expression levels in Saos-2 cells, which were exposed with $2.5 \mu \mathrm{M}$ and 20 $\mu \mathrm{M} \quad \mathrm{N}$-(4-chlorophenyl)-1H-indole-2carboxamide doses, that we picked from our data in Table 3. We found that the cells exposed to the doses of $2.5 \mu \mathrm{M}$ and $20 \mu \mathrm{M} \mathrm{N}$ (4-chlorophenyl) -1 H-indole-2-carboxamide, shown in Figure 3, decrease the expression of the gradient according to the control. No difference in ezrin expression between drug doses was observed (Table 3).
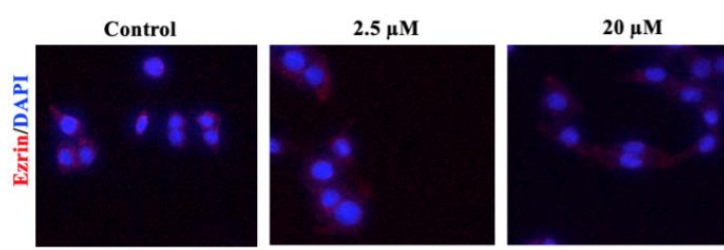

Figure 3. Immunofluorescence staining with Ezrin (Tyr478) polyclonal antibody in the Saos 2 cell line at doses of $2.5 \mu \mathrm{M}$ and $20 \mu \mathrm{M}$ $\mathrm{N}$-(4-chlorophenyl)-1H-indole-2-

carboxamide. It shows specific staining of the plasma membrane with red. 
Table 3. Table showing that total ezrin expression in Saos-2 cell lines changes of grades

\begin{tabular}{|l|c|c|c|}
\cline { 2 - 4 } \multicolumn{1}{c|}{} & Control & $2.5 \mu \mathrm{M}$ & $20 \mu \mathrm{M}$ \\
\hline $\begin{array}{l}\text { Ezrin } \\
\text { expression } \\
\text { levels }\end{array}$ & +++ & ++ & ++ \\
\cline { 2 - 4 } & \multicolumn{3}{|c|}{$\mathrm{n}=100$ cells were analyzed per each group. } \\
\hline
\end{tabular}

$($ High $=+++$, moderate $=++)$

\section{DISCUSSION}

Osteosarcoma is the most common type of bone cancer in children and adolescents (19). Unfortunately, there is no effective treatment for controlling the recurrence and metastasis of osteosarcoma. It is therefore important to find a potential candidate for the treatment of osteosarcoma. Recent studies showed that different indole derivatives are exert anticancer effects on various cancer cells, such as colon, liver, lung cancer and osteosarcoma (15). In this study, for the first time the newly synthesized indole derivative molecule, $\mathrm{N}$ - (4chlorophenyl) -1 H-indole-2-carboxamide was evaluated for resistance in vitro osteosarcoma cell line. The MTT proliferation assay results showed that the Saos-2 cell line, which treated with $2.5 \mu \mathrm{M}$ of N- (4-Chlorophenyl) $-1 \mathrm{H}$ Indole-2-Carboxamide significantly inhibited cell proliferation in a dose-dependent manner (Figure 1). We suggest that low doses of N- (4Chlorophenyl) -1 H-Indole-2-Carboxamide may affect the Saos- 2 cell line by inhibiting the effect of tyrosine kinases by antioxidant properties.

Imatinib mesylate exerts antiproliferative activities in osteosarcoma cell lines by affecting thyrosine kinase receptors and inducing cell death and cell migration (13). In our study we found that, imatinib mesylate doses were optimized with our experimental design which is parallel to the findings in recent studies (14). We compared two different derivatives on the same cell line and we showed that $2.5 \mathrm{uM} \mathrm{N}$ - (4-chlorophenyl) $-1 \mathrm{H}$ - indole-2-carboxamide were effective for Saos2 cell line (Figure 2 ). Thus we suggest that even lower doses of $\mathrm{N}$ - (4-chlorophenyl) $-1 \mathrm{H}$ indole-2-carboxamide can be effective on osteosarcoma cell lines when we compare with imatinib mesylate pharmacological doses.

Opportunities to improve outcomes for patients who present with metastases and those at-risk for progression and metastasis require an improved understanding of cancer progression and metastasis. With this goal in mind recent studies have identified ezrin as a metastasis-associated protein that associated with osteosarcoma. In our study, we found that the ezrin expression levels were modarate after treatment of N- (4-Chlorophenyl) $-1 \mathrm{H}$ Indole-2-Carboxamide. We suggest that N- (4Chlorophenyl) -1 H-Indole-2-Carboxamide and ezrin working mechanism may be a key role for being target to anti-proliferative effects on Saos cell line (Figure 3).

\section{Conclusion}

New treatment options for advanced osteosarcoma remain limited. Therefore, there is a real need to develop new approaches for optimizing existing treatment strategies and treating osteosarcoma, so new molecular targeted therapies with more effective and less toxicity are needed. With this project, we evaluated the anti-proliferation effects of $\mathrm{N}$ (4-Chlorophenyl) -1 H-Indole-2-Carboxamide in Saos- 2 cells. We showed that the inhibition mechanism of $\mathrm{N}$ - (4-Chlorophenyl) -1 $\mathrm{H}$ Indole-2-Carboxamide can be related to ezrin protein, which is an actin binding protein and regulator of cell cytoskeleton in Saos-2 cells. In conclusion, all these results showed that $\mathrm{N}$ (4-Chlorophenyl) -1 H-Indole-2-Carboxamide can be developed as a potential therapeutic agent for inhibiting osteosarcoma growth and metastasis.

\section{Çıkar Çatışması: Yok}




\section{REFERENCES}

1. Buck DW, Dumanian GA. Bone Biology and Physiology. Plastic and Reconstructive Surgery2012; 129: 1314-1320.

2. Florencio-Silva R, Sasso GRDS, Sasso-Cerri E, Simões MJ, Cerri PS. Biology of Bone Tissue: Structure, Function, and Factors That Influence Bone Cells. BioMed Research International2015; 2015: 1-17.

3. Ibrahim T, Mercatali L, Amadori D. Bone and cancer: the osteoncology. Clin Cases Miner Bone Metab 2013; 10: 121-123.

4. Rodan GA. The development and function of the skeleton and bone metastases. Cancer2003; 97: 726-732.

5. Geller DS, Gorlick R. Osteosarcoma: a review of diagnosis, management, and treatment strategies. Clin Adv Hematol Oncol 2010; 8: 705-718.

6. Carlin BI, Andriole GL. The natural history, skeletal complications, and management of bone metastases in patients with prostate carcinoma. Cancer 2000; 88: 2989-2994.

7. Chiarugi P, Giannoni E. Anchorage-Dependent Cell Growth: Tyrosine Kinases and Phosphatases Meet Redox Regulation. Antioxidants \& Redox Signaling2005; 7: 578-592.

8. Gschwind A, Fischer OM, Ullrich A. The discovery of receptor tyrosine kinases: targets for cancer therapy. Nat Rev Cancer 2004; 4: 361-370.

9. Lemmon MA, Schlessinger J. Cell signaling by receptor tyrosine kinases. Cell 2010; 141: 11171134.

10. Benhar M, Engelberg D, Levitzki A. ROS, stressactivated kinases and stress signaling in cancer. EMBO Rep 2002; 3: 420-425.

11. Abdollahi $M$, Larijani $B$, Rahimi $R$, Salari $P$. Role of oxidative stress in osteoporosis. Therapy $2005 ; 2$ : 787-796.
12. Brounais B, Ruiz C, Rousseau J, Lamoureux F, Blanchard F, Heymann D et al. Novel anti-cancer strategy in bone tumors by targeting molecular and cellular modulators of bone resorption. Recent Pat Anticancer Drug Discov 2008; 3: 178-186.

13. Yamaguchi SI, Ueki A, Sugihara E, Onishi N, Yaguchi T, Kawakami Y et al.Synergistic antiproliferative effect of imatinib and adriamycin in platelet-derived growth factor receptorexpressing osteosarcoma cells. Cancer Science 2015; 106: 875-882.

14. Gobin B, Moriceau G, Ory B, Charrier C, Brion R, Blanchard $\mathrm{F}$ et al. Imatinib mesylate exerts antiproliferative effects on osteosarcoma cells and inhibits the tumour growth in immunocompetent murine models. PLoS One 2014; 9: e90795.

15. Kim YS, Milner JA. Targets for indole-3-carbinol in cancer prevention. J Nutr Biochem 2005; 16: 6573

16. Li Y, Kong D, Ahmad A, Bao B, Sarkar FH. Antioxidant function of isoflavone and 3,3'diindolylmethane: are they important for cancer prevention and therapy? Antioxid Redox Signal 2013; 19: 139-150.

17. Ölgen $S$, Varol P, Çoban T, Nebioğlu D. Synthesis and evaluation of $\mathrm{N}$-substituted indole-3carboxamide derivatives as inhibitors of lipid peroxidation and superoxide anion formation. Journal of Enzyme Inhibition and Medicinal Chemistry2008; 23: 334-340.

18. Ölgen S, Kiliç Z, Ada AO, Çoban T. Synthesis and evaluation of novel $\mathrm{N}-\mathrm{H}$ and $\mathrm{N}$-substituted indole2- and 3-carboxamide derivatives as antioxidants agents. Journal of Enzyme Inhibition and Medicinal Chemistry2007; 22: 457-462.

19. Öztürk R, İnce $B$, Karakoç $Y$, Arıkan ŞM, Yapar AE, Erdoğdu YI, et al. Evaluation Of Demographic And Clinicopathological Characteristics Of Osteosarcoma Patients. Acta Oncol Tur.. 2019; 52(2): 266-270. | Doi: 10.5505/aot.2019.60234 